\title{
Papel do treinamento físico no conteúodo da proteína rock e seus efeitos sobre a sinalização da insulina em músculo esquelético de camundongos obesos.
}

Vitor Rosetto Muñoz (IC), Luciana Santos Souza Pauli (PG), Bárbara de Almeida Rodrigues (PG), Rodolfo Marinho (PG), José Diego Botezelli (PQ), Leandro Pereira de Moura (PQ), Eloize Cristina Chiarreotto Ropelle (PG), Dennys Esper Cintra (PQ), Adelino Sanchez Ramos da Silva (PQ), Eduardo Rochete Ropelle (PQ), José Rodrigo Pauli (PQ).

\section{Resumo}

A proteína $R O C K$ apresenta grande importância na sinalização de insulina no músculo esquelético contribuindo (substâncialmente) com a captação de glicose. Como o exercício físico é capaz de melhorar a homeostase glicêmica, o objetivo deste estudo foi investigar se o exercício pode aumentar os níveis proteicos de ROCK resultando numa melhora na transdução do sinal da insulina e redução da hiperglicemia em camundongos obesos.

Palavras Chave: Resistência à insulina, Exercício Físico, Obesidade.

\section{Introdução}

A situação de resistência à insulina está presente em indivíduos obesos numa condição prédiabetes e acomete grande parte da população. No músculo esquelético a resistência desse hormônio atenua a captação de glicose para o meio intracelular e colabora para a hiperglicemia ${ }^{(1)}$. Recém descoberta como atuante na sinalização da insulina, a proteína Rhoquinase $(R O C K)$ tem efeitos positivos nessa via aumentando a fosforilação do substrato do receptor de insulina-1 (IRS-1) culminando numa melhora de até $50 \%$ da captação de glicose no músculo esquelético ${ }^{(2)}$. Objetivos: $O$ objetivo desse estudo foi investigar o papel do exercício físico na regulação da proteína $R O C K$ assim como seus efeitos na sinalização da insulina no músculo esquelético de camundongos obesos. Métodos: Foram utilizados camundongos Swiss com 4 semanas de vida e separados nos seguintes grupos: Controle magro $(\mathrm{C}, \mathrm{n}=5)$, Obeso sedentário $(\mathrm{O}-\mathrm{S}, \mathrm{n}=5)$ e Obeso treinado (OB-T, $\mathrm{n}=5)$. Os animais obesos receberam uma dieta rica em gordura por 8 semanas para indução da obesidade. $\mathrm{O}$ treinamento físico teve a duração de 8 semanas dividido em 2 fases de 4 semanas. Foi avaliada a glicemia e insulinemia de jejum. Foi realizado o teste de tolerância à insulina (TTI). Para identificação do conteúdo proteico e fosforilação das proteínas AKT e conteudo proteico da $R O C K 1$ foi utilizada a técnica de imunoblot 24 horas após a ultima sessão de esforço de cada animal.

\section{Resultados e Discussão}

Os animais obesos ficaram mais hiperglicêmicos e hiperinsulinêmicos em relação ao grupo controle. Os animais obesos ficaram menos sensíveis à insulina em relação ao grupo controle. Ao contrário, o exercício físico atenuou estes aspectos e foi capaz de aumentar o conteúdo da proteína $R O C K$ e a fosforilação da AKT no músculo esquelético em relação ao grupo obeso sedentário, colaborando com uma melhora na via de sinalização da insulina nesse tecido.

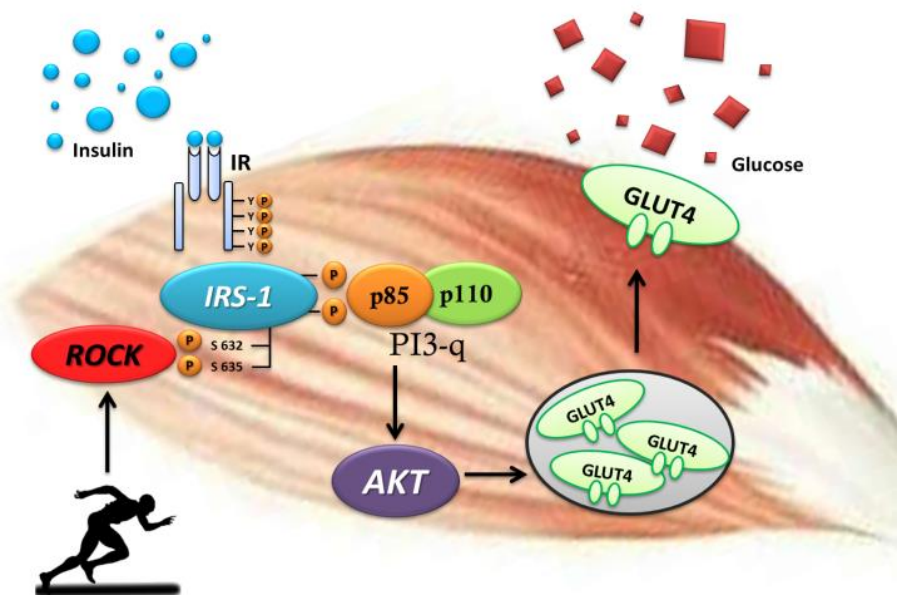

Figura 1. Figura esquemática da proteína $R O C K$ e via da insulina no músculo esquelético.

\section{Conclusões}

O treinamento físico aumenta o conteúdo da proteína $R O C K$ no músculo de animais obesos e melhora a via de sinalização da insulina no músculo esquelético, induzindo melhoras metabólicas no animais obesos. Tal fato pode ter efeito preventivo sobre o desnvolvimento do diabetes do tipo 2 .

\section{Agradecimentos}

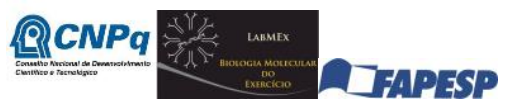

1. Pauli, JR et al. Arq Bras. Endrocrinol. Metabol. 2009, 53, 399-408. 2. Furukawa, N e Kim, YB. Cell Metabolism. 2005, 2, 119-129. 